\title{
Quantitative relations between exposure to respirable coalmine dust and coalworkers' simple pneumoconiosis in men who have worked as miners but have left the coal industry
}

\author{
C A SOUtAR, W M MAClaREN, R ANNis, AND A W T MELVille
}

From the Institute of Occupational Medicine, Edinburgh EH8 9SU, UK

\begin{abstract}
Present estimates of the quantitative relations between exposure to mixed respirable coalmine dust and risk of developing coalworkes' simple pneumoconiosis are based on studies of working miners. These studies did not include men who had been miners but had left the coal industry, and it was not known whether the estimates of risk were also appropriate for these men. The results are reported of a study in which the dust/disease relations in men who have been miners but have left the industry have been compared with those in men who have remained in it. A sample of 17738 men who were first examined when working in 24 British collieries in the 1950s has been followed up about 22 years later. It was possible to examine $61 \%$ of the survivors, $44 \%$ of the original sample. Simple pneumoconiosis was more frequent among men (particularly older men) who had left the industry than among those who had stayed in it. A detailed analysis did not show any systematic or statistically significant difference between men who stayed and men who left in the quantitative relations between dust exposure and simple pneumoconiosis. Present estimates of risk of simple pneumoconiosis in relation to exposure to mixed respirable dust in working miners adequately describe the relation found in men who have been miners but have left the industry.
\end{abstract}

Current estimates of the risks of a coalminer developing simple pneumoconiosis are based on the relations between pneumoconiosis and individual cumulative exposure to mixed respirable dust. ${ }^{1-3}$ These estimates were based on studies of working miners that did not include men who had been miners but had left the industry. Some men who left the industry may have done so because their health was poor, and their responses to dust exposure might differ from those evident in working miners.

The purpose of the present work was to establish whether, and to what extent, earlier estimates of dust exposure-specific risks of developing different degrees of coalworkers' simple pneumoconiosis, based on data from working coalminers, may differ systematically from risks experienced by all miners, including those who have left the industry.

\section{Subjects}

During the Pneumoconiosis Field Research of the Accepted 20 May 1985
National Coal Board men working in selected collieries in Britain have been examined at medical surveys conducted at roughly five year intervals. The sample for the present study was selected from men examined during the first round of medical surveys conducted at 24 collieries between 1953 and 1958. The geographical locations of these collieries have been described previously ${ }^{3}$ and are distributed over all the British coalfields. A total of 31676 men was seen originally, representing more than $90 \%$ of the men working in these collieries at that time. For this follow up study a sample was selected that included all men whose chest radiograph at that time was classified as category 1 or greater pneumuconiosis on the ILO scale $^{4}$ (3645 men) and about half the remainder, selected randomly but proportionally by colliery and within five year age groups (14093 men) giving a total sample of 17738 men.

\section{Methods}

Men in the sample who had died by the time of follow up examination were identified by methods described 
in a recent mortality study. ${ }^{5}$ The remaining men were traced if possible through medical research and colliery records, forwarding letters by the Department of Health and Social Security to men who had moved (without release of these addresses to us), consultations with trade union officials and other local search procedures, and all those traced were invited to participate in the study. The follow up examinations of men participating took place between 1974 and 1980.

At each medical examination a full size chest radiograph was taken and at second and later surveys a questionnaire of respiratory symptoms and smoking habits was administered by trained personnel. ${ }^{6}$

All chest radiographs taken at follow up were read independently and in random order by a panel of five readers (of whom four were not medically qualified) who had trained themselves ${ }^{7}$ to interpret chest radiographs according to the ILO U/C classification of the appearances of pneumoconiosis. ${ }^{8}$ Three physicians experienced in the interpretation of the appearances of pneumoconiosis also classified a subset of 760 radiographs of men in this study. This subset of radiographs had been read, in an earlier phase of this study, ${ }^{9}$ for the purposes of assessing changes in radiographic appearances after men had left the industry, and some comparisons between the two panels' readings are made in this report.

Occupational histories based on employment records were recorded for each man, ${ }^{2}$ in which the time each man spent in a changing series of occupational groups within each colliery was recorded continuously for the period of the research. For periods during which detailed records were not kept-for example, before the start of the research in 1953 or when the research ceased at a colliery before the follow up survey - occupational histories were obtained by interview and each mining job allocated to one of six broad categories of exposure.

Frequent monitoring of airborne respirable dust concentrations in all occupational groups in the $24 \mathrm{~d}$ collieries was carried out for an approximately ten. year period after the initial survey. ${ }^{10}$ After the first ten $\overrightarrow{\overrightarrow{\vec{\omega}}}$ years, monitoring continued in ten collieries until the follow up surveys, but research measurements ceased in the remaining 14 collieries (though dust control $\frac{\bar{c}}{\bar{c}}$ measurements continued). Estimates of dust concen- $\vec{\nabla}$ trations existing in these 14 collieries during this latter period were therefore derived from less detailed mea-ळ) surements than during the previous period, or at the $\vec{\circ}$ other collieries during the latter period. Estimateswere based on measurements taken for dust controlw purposes at the control point, 70 metres from the downwind end of the coalface. These concentrations were converted to those likely to have been experi-? enced by men working in different parts of the collieryct by applying conversion factors, based on the period $\vec{i}$ when both control and research measurements werec being made, for the six broad environmental catego-을 ries. Concentrations existing in all collieries before the start of the research (which had not been measured) were allocated the average values measured during the first ten years of the research, grouped within each colliery according to the six broad environmental categories. The hours each man worked in each $\mathbb{\infty}_{\infty}$ occupational group were multiplied by the respirable ${ }^{\circ}$ dust concentrations for the groups and summed to give each individual's cumulative exposure to respira-s ble coalmine dust. ${ }^{1210}$

\section{METHODS OF ANALYSIS}

From the five readers' classifications of the chest $\stackrel{2}{=}$ radiographs, median readings for profusion of small 3 rounded opacities were used for the analysis. The dust/disease relations in men who were working min-o ers at the time of follow up survey compared with those in men who had left the industry before compul- $\Phi$ sory retirement age (men who were ex-miners at the time of follow up survey and who were under 65). The 3 relations in men over 65 , who included men who had

Table 1 Characteristics of the sample at the time of first survey, grouped according to whether they were examined or not at follow up. The numbers of men on which these data are based vary according to the completeness of the data. (Standard deviations in parentheses)

\begin{tabular}{|c|c|c|c|c|c|}
\hline Characteristic & $\begin{array}{l}\text { Examined } \\
\text { (miners) }\end{array}$ & $\begin{array}{l}\text { Examined } \\
\text { (ex-miners) }\end{array}$ & $\begin{array}{l}\text { Examined } \\
\text { (unknown status) }\end{array}$ & $\begin{array}{l}\text { Not examined } \\
\text { (including those who } \\
\text { had died) }\end{array}$ & All \\
\hline $\begin{array}{l}\text { Mean age (years) } \\
\text { No of men }\end{array}$ & 2547 (7) & $\begin{array}{r}41(11) \\
4526\end{array}$ & $\begin{array}{l}40(13) \\
45\end{array}$ & $\begin{array}{r}44(14) \\
10620\end{array}$ & $\begin{array}{l}42(14) \\
17738\end{array}$ \\
\hline $\begin{array}{l}\text { Mean dust exposure }\left(\mathrm{gh} / \mathrm{m}^{3}\right) \\
\text { No of men } \\
\text { No of men with inadequate dust } \\
\text { exposure records }\end{array}$ & $\begin{array}{r}73(71) \\
2512 \\
35\end{array}$ & $\begin{array}{l}133(110) \\
4377 \\
149\end{array}$ & $\begin{array}{c}111(104) \\
41 \\
4\end{array}$ & $\begin{array}{l}140(118) \\
7609 \\
3011\end{array}$ & $\begin{array}{l}126(111) \\
14539 \\
3199\end{array}$ \\
\hline $\begin{array}{l}\text { Prevalence of category } 2 / 1 \text { or } \\
\text { greater small rounded opacities } \\
\text { No of men }\end{array}$ & $\begin{array}{l}2 \cdot 9 \% \\
2547\end{array}$ & $\begin{array}{l}9 \cdot 4 \% \\
4526\end{array}$ & $\begin{array}{c}2 \cdot 2 \% \\
45\end{array}$ & $\begin{array}{l}11 \cdot 1 \% \\
10620\end{array}$ & $\begin{array}{l}9.4 \% \\
17738\end{array}$ \\
\hline
\end{tabular}


Table 2 Percentage of men (with numbers in parentheses) with category 2 or greater simple pneumocoiosis or PMF at first survey, by dust exposure up to first survey, and whether or not the men were examined at follow up survey (3199 men are excluded from this table because of inadequate dust exposure data for the period before first survey)

\begin{tabular}{|c|c|c|c|c|c|c|c|c|}
\hline \multirow{2}{*}{$\begin{array}{l}\text { Whether or not examined } \\
\text { at follow up }\end{array}$} & \multicolumn{8}{|c|}{ Dust exposure $\left(\mathrm{g} h / \mathrm{m}^{1}\right)$} \\
\hline & -50 & -100 & -150 & -200 & -300 & -400 & $>400$ & All groups \\
\hline $\begin{array}{l}\text { Examined } \\
\text { Not examined }\end{array}$ & $\begin{array}{c}0 \cdot 0 \\
(2489) \\
10 \cdot 2 \\
(2093)\end{array}$ & $\begin{array}{l}0 \cdot 9 \\
(1373) \\
2 \cdot 2 \\
(1331)\end{array}$ & $\begin{array}{l}5 \cdot 3 \\
(1016) \\
9 \cdot 7 \\
(1199)\end{array}$ & $\begin{array}{c}9.8 \\
(756) \\
14.7 \\
(950)\end{array}$ & $\begin{array}{c}24 \cdot 4 \\
(934) \\
25 \cdot 2 \\
(1238)\end{array}$ & $\begin{array}{l}30 \cdot 3 \\
(264) \\
26 \cdot 2 \\
(553)\end{array}$ & $\begin{array}{c}36 \cdot 7 \\
(98) \\
27 \cdot 4 \\
(245)\end{array}$ & $\begin{array}{c}7 \cdot 0 \\
(6930) \\
11 \cdot 1 \\
(7609)\end{array}$ \\
\hline
\end{tabular}

left prematurely as well as men who had stayed in the industry until compulsory retirement age, have not been quoted here since no group of miners of similar ages existed for comparison.

Men were classified as non-smokers, cigarette smokers, pipe and cigar smokers, and ex-smokers according to their answers to the questionnaire at follow up. Preliminary analyses indicated that smoking habit and age appeared to influence the prediction of category $0 / 1$ or greater small rounded opacities and age to the prediction of category $2 / 1$ or greater opacities. These factors were therefore included as concomitant variables in analyses aimed at estimating the relations of dust exposure with radiographic apearance. Total time worked in the industry was found to contribute only trivially to the prediction of small rounded opacities after allowing for dust exposure and age and was not included in the analyses of the effect of dust.

The overall difference between miners and exminers in the relations of pneumoconiosis frequency with dust exposure was studied in a logistic model that included the effects of age and smoking habit, and allowed for different effects of dust for each colliery. The predicted frequencies of small opacities category $0 / 1$ or greater, and category $2 / 1$ or greater for miners and ex-miners under 65 were compared over the full range of dust exposure and age. Details of the analysis are described in the appendix.

\section{Results}

POPULATIONS EXAMINED

By the time of follow up $34 \%$ of the sample of 17738 men had died and it was possible to examine $61 \%$ of the survivors ( 7118 men, $44 \%$ of the original sample), the remainder being untraced or unable or unwilling to attend. The men not examined at follow up had included more older men than the examined groups, and at the time of first survey the men not examined had experienced similar exposures to dust and had a similar frequency of simple pneumoconiosis to exminers who were examined at follow up. By contrast, men still working in the industry at follow up ("miners") had experienced less exposure to dust and had a lower frequency of pneumoconiosis at first survey than either of the other two groups (table 1).

INFLUENCE OF DUST EXPOSURE AT FIRST SUR VEY The frequencies of simple pneumoconiosis category 2 or greater at first survey in men grouped by ranges of dust exposure to first survey are shown in table 2, separated according to their attendance or nonattendance at follow up (those who died are included). It can be seen that the response to dust exposure appears to be less steep in the non-examined men than the examined. The relation between dust exposure and presence of simple pneumoconiosis category 2 or greater at first survey was further examined in a logistic regression model, taking account of age. Men subsequently not examined were found to have a slightly less severe response to their dust exposure than men subsequently examined $(p<0.001)$.

INFLUENCE OF DUST EXPOSURE AT FOLLOW UP SUR VEY

Absence of information on miner/ex-miner status, dust exposures, smoking data, or radiographic results

Table 3 Characteristics of the men at the time of follow up examination. (Standard deviations in parentheses except where indicated). Percentages are of the number of men in the groups

\begin{tabular}{|c|c|c|c|c|}
\hline & Miners & Ex-miners $<65$ & Ex-miners $>65$ & All \\
\hline $\begin{array}{l}\text { No of men } \\
\text { Age at follow up (years) } \\
\text { Dust exposure to follow up } \\
\text { No with: }\end{array}$ & $\begin{array}{c}2255 \\
53(7) \\
173(102)\end{array}$ & $\begin{array}{c}1953 \\
54(8) \\
149(113)\end{array}$ & $\begin{array}{c}1943 \\
71(5) \\
226(125)\end{array}$ & $\begin{array}{c}6151 \\
59(11) \\
182(118)\end{array}$ \\
\hline $\begin{array}{l}0 / 1+\text { small rounded opacities } \\
2 / 1+\text { small rounded opacities }\end{array}$ & $\begin{array}{l}606(27 \%) \\
149(7 \%)\end{array}$ & $\begin{array}{l}551(28 \%) \\
169(9 \%)\end{array}$ & $\begin{array}{l}796(41 \%) \\
285(15 \%)\end{array}$ & $\begin{array}{r}1953(32 \%) \\
603(10 \%)\end{array}$ \\
\hline
\end{tabular}



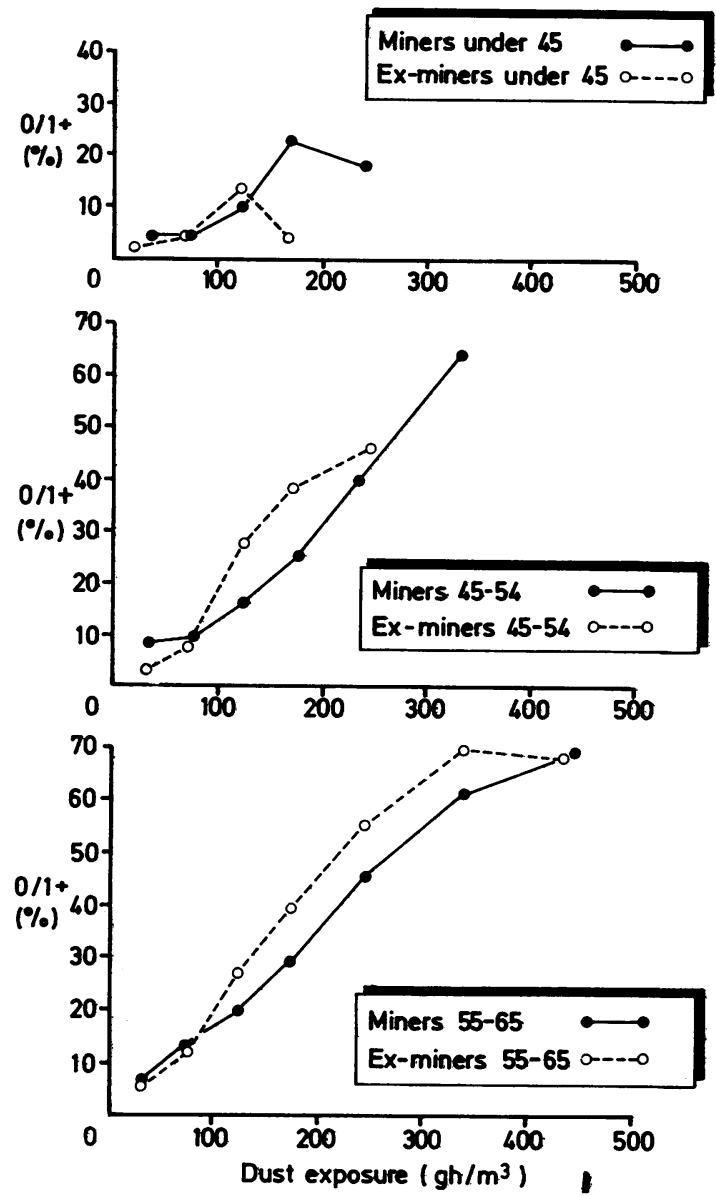

Fig 1 Observed frequencies of small rounded opacities category $0 / 1$ or greater in miners and ex-miners under 65 , within three age groupings.

at follow up reduced the study group from 7118 to 6151 men. Some characteristics of these men are shown in table 3. Ex-miners over 65 had experienced higher lifetime exposures to respirable dust than the groups of younger men and had higher frequencies of small rounded opacities. Ex-miners under 65 had a similar frequency of category $0 / 1$ or greater small rounded opacities to working miners, and a slightly higher frequency of category $2 / 1$ or greater opacities.

Figure 1 shows the observed frequencies of small rounded opacities category $0 / 1$ or greater for miners and ex-miners under 65 in three age groups, and according to dust exposure ranges. The expected relation with dust exposure is apparent and for the groups of men over 45 the frequencies of these opacities within dust exposure ranges appear greater in most cases in ex-miners than miners. Over most of the
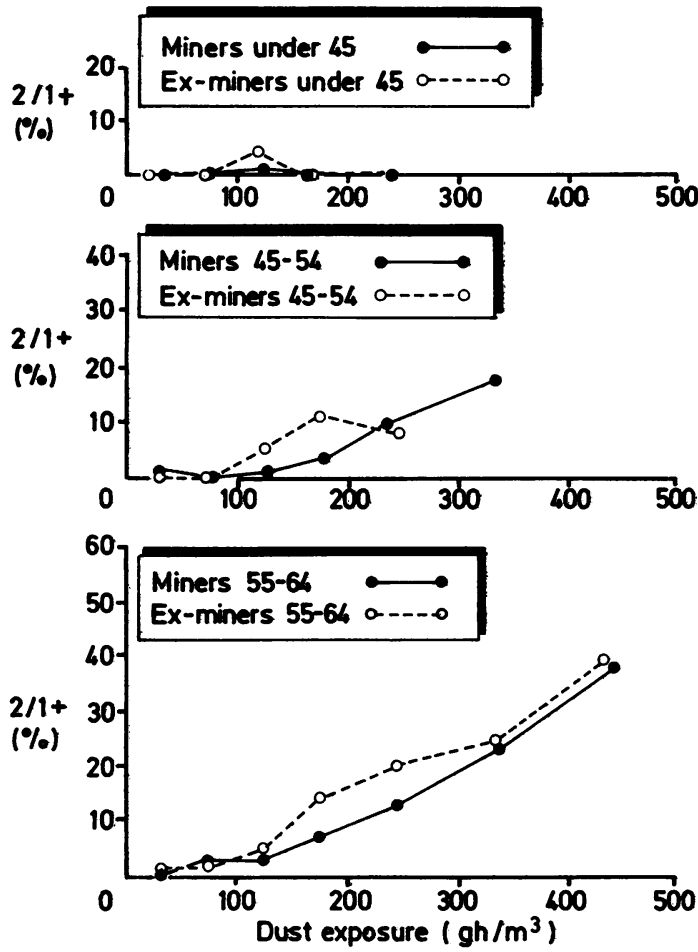

Fig 2 Observed frequencies of small rounded opacities category 2/1 or greater in miners and ex-miners under 65 , within three age groupings.

dust exposure ranges the lines appear parallel, suggesting that the difference between miners and ex-0 miners is not the consequence of different responses to dust exposure. In the lower dust exposure ranges there $\frac{\mathbb{D}}{3}$ does appear to be some divergence of the frequencies of these opacities, possibly suggesting a more severe 3 response of ex-miners to the lower dust exposure ranges.

Figure 2 shows the observed frequencies for category $2 / 1$ or greater small rounded opacities. Similar observations may be made on these results as on those for category $0 / 1$ or greater opacities.

These apparent differences take no account of ${ }^{N}$ differences between collieries in proportions of men $\mathrm{N}$ who were ex-miners, in mean dust exposure, or in the effects of dust exposure. The frequency at follow up $\omega$ examination of small rounded opacities category $0 / 12$ or greater and category $2 / 1$ or greater are listed for each colliery in table 4 , together with the mean dust ${ }_{\infty}^{\infty}$ exposures. There were pronounced differences? between collieries in frequencies and exposure.

Differences in frequency between these groups were $\stackrel{\circ}{\overparen{ }}$ examined in a logistic model, allowing for differences $\frac{?}{\mathscr{}}$ 
Quantitative relations between exposure to respirable coalmine dust and simple pneumoconiosis

Table 4 Number of men, ages, dust exposure, and prevalence (\%) of profusion of small rounded opacities, all at follow up survey, by colliery, for three groups of men: (i) miners, (ii) ex-miners younger than 65, (iii) ex-miners, 65 or more

\begin{tabular}{|c|c|c|c|c|c|c|c|c|c|c|c|c|c|c|c|c|}
\hline \multirow[t]{3}{*}{ Area } & \multirow[t]{3}{*}{ Colliery } & \multicolumn{3}{|c|}{ No of men } & \multicolumn{3}{|c|}{$\begin{array}{l}\text { Age at follow up } \\
\text { survey (years) }\end{array}$} & \multicolumn{3}{|c|}{$\begin{array}{l}\text { Dust exposure } \\
\left(\mathrm{g} \mathrm{h} / \mathrm{m}^{3}\right)\end{array}$} & \multirow{2}{*}{\multicolumn{6}{|c|}{$\begin{array}{l}\text { Prevalence }(\%) \text { of profusion of small } \\
\text { rounded opacities } \\
\geqslant 0 / l \quad \geqslant 2 / 1\end{array}$}} \\
\hline & & \multirow{2}{*}{ (i) } & \multirow{2}{*}{ (ii) } & \multirow{2}{*}{$\overline{(i i i)}$} & \multirow{2}{*}{$\overline{\text { (i) }}$} & \multirow{2}{*}{ (ii) } & \multirow{2}{*}{$\overline{(i i i)}$} & \multirow{2}{*}{$\overline{(i)}$} & \multirow{2}{*}{ (ii) } & \multirow{2}{*}{$\overline{(i i i)}$} & & & & & & \\
\hline & & & & & & & & & & & (i) & (ii) & (iii) & (i) & (ii) & (iii) \\
\hline Scotland & $\begin{array}{l}\mathrm{J} \\
\mathbf{O} \\
\mathbf{P} \\
\mathbf{S}\end{array}$ & $\begin{array}{r}146 \\
16 \\
120 \\
50\end{array}$ & $\begin{array}{l}43 \\
88 \\
97 \\
55\end{array}$ & $\begin{array}{l}62 \\
90 \\
49 \\
34\end{array}$ & $\begin{array}{l}51.9 \\
53.4 \\
50.6 \\
51.5\end{array}$ & $\begin{array}{l}54 \cdot 5 \\
54 \cdot 1 \\
56 \cdot 3 \\
50 \cdot 3\end{array}$ & $\begin{array}{l}71 \cdot 2 \\
71 \cdot 1 \\
70 \cdot 0 \\
69 \cdot 1\end{array}$ & $\begin{array}{r}128.0 \\
112.7 \\
75.9 \\
74.9\end{array}$ & $\begin{array}{l}84 \cdot 2 \\
76 \cdot 7 \\
74 \cdot 8 \\
42 \cdot 6\end{array}$ & $\begin{array}{r}144.8 \\
151.1 \\
98.2 \\
83.8\end{array}$ & $\begin{array}{r}16.4 \\
25.0 \\
6.7 \\
0.0\end{array}$ & $\begin{array}{r}7 \cdot 0 \\
10.2 \\
8.2 \\
3.6\end{array}$ & $\begin{array}{l}25 \cdot 8 \\
34 \cdot 4 \\
12 \cdot 2 \\
17 \cdot 6\end{array}$ & $\begin{array}{l}0.0 \\
0.0 \\
0.8 \\
0.0\end{array}$ & $\begin{array}{l}0.0 \\
0.0 \\
0.0 \\
1.8\end{array}$ & $\begin{array}{r}8 \cdot 1 \\
12.2 \\
2.0 \\
8.8\end{array}$ \\
\hline $\begin{array}{l}\text { North east } \\
\text { Eigland }\end{array}$ & $\begin{array}{l}\mathbf{D} \\
\mathbf{T} \\
\mathbf{Y} \\
\mathbf{Z}\end{array}$ & $\begin{array}{r}57 \\
23 \\
228 \\
143\end{array}$ & $\begin{array}{r}51 \\
198 \\
64 \\
70\end{array}$ & $\begin{array}{r}47 \\
165 \\
139 \\
81\end{array}$ & $\begin{array}{l}52 \cdot 1 \\
51 \cdot 6 \\
54 \cdot 6 \\
52 \cdot 6\end{array}$ & $\begin{array}{l}53 \cdot 2 \\
55 \cdot 1 \\
58 \cdot 4 \\
56 \cdot 3\end{array}$ & $\begin{array}{l}69 \cdot 7 \\
71 \cdot 4 \\
69 \cdot 7 \\
70 \cdot 3\end{array}$ & $\begin{array}{r}82.7 \\
138.2 \\
189.9 \\
181.5\end{array}$ & $\begin{array}{r}50.7 \\
160.4 \\
234.7 \\
153.1\end{array}$ & $\begin{array}{r}36 \cdot 1 \\
250 \cdot 6 \\
254.6 \\
233.7\end{array}$ & $\begin{array}{r}0.0 \\
13 \cdot 0 \\
30 \cdot 3 \\
13 \cdot 3\end{array}$ & $\begin{array}{r}2 \cdot 0 \\
31 \cdot 3 \\
45 \cdot 3 \\
11 \cdot 4\end{array}$ & $\begin{array}{r}6 \cdot 4 \\
42 \cdot 4 \\
36 \cdot 7 \\
18 \cdot 5\end{array}$ & $\begin{array}{l}0.0 \\
8.7 \\
7.0 \\
0.7\end{array}$ & $\begin{array}{r}0.0 \\
12.1 \\
10.9 \\
1.4\end{array}$ & $\begin{array}{r}2 \cdot 1 \\
18 \cdot 8 \\
10 \cdot 1 \\
2.5\end{array}$ \\
\hline $\begin{array}{l}\text { Yorkshire and } \\
\text { Yottinghamshire }\end{array}$ & $\begin{array}{l}\mathbf{G} \\
\mathbf{K} \\
\mathbf{Q} \\
\mathbf{X}\end{array}$ & $\begin{array}{l}143 \\
191 \\
157 \\
179\end{array}$ & $\begin{array}{l}59 \\
84 \\
12 \\
78\end{array}$ & $\begin{array}{r}90 \\
114 \\
30 \\
109\end{array}$ & $\begin{array}{l}52 \cdot 9 \\
52 \cdot 6 \\
52 \cdot 4 \\
51 \cdot 4\end{array}$ & $\begin{array}{l}56 \cdot 8 \\
50.9 \\
54 \cdot 1 \\
51 \cdot 7\end{array}$ & $\begin{array}{l}71 \cdot 1 \\
71 \cdot 2 \\
70 \cdot 2 \\
72 \cdot 4\end{array}$ & $\begin{array}{l}126 \cdot 5 \\
150 \cdot 1 \\
227.9 \\
177.7\end{array}$ & $\begin{array}{r}101.0 \\
95.9 \\
229.7 \\
133.0\end{array}$ & $\begin{array}{l}141 \cdot 2 \\
205 \cdot 5 \\
359 \cdot 7 \\
258 \cdot 5\end{array}$ & $\begin{array}{l}32 \cdot 9 \\
29 \cdot 3 \\
14 \cdot 7 \\
48.0\end{array}$ & $\begin{array}{l}28 \cdot 8 \\
10 \cdot 7 \\
16 \cdot 7 \\
43 \cdot 6\end{array}$ & $\begin{array}{l}50 \cdot 0 \\
36 \cdot 8 \\
20 \cdot 0 \\
72 \cdot 5\end{array}$ & $\begin{array}{r}4 \cdot 2 \\
7 \cdot 3 \\
1 \cdot 3 \\
12 \cdot 8\end{array}$ & $\begin{array}{r}11.9 \\
4.8 \\
0.0 \\
10.3\end{array}$ & $\begin{array}{r}21 \cdot 1 \\
10 \cdot 5 \\
3 \cdot 3 \\
28 \cdot 4\end{array}$ \\
\hline Midlands & $\begin{array}{l}\mathrm{C} \\
\mathrm{N}\end{array}$ & $\begin{array}{l}70 \\
47\end{array}$ & $\begin{array}{l}76 \\
31\end{array}$ & $\begin{array}{r}122 \\
41\end{array}$ & $\begin{array}{l}53 \cdot 6 \\
51 \cdot 5\end{array}$ & $\begin{array}{l}54 \cdot 0 \\
54 \cdot 4\end{array}$ & $\begin{array}{l}72 \cdot 2 \\
71 \cdot 3\end{array}$ & $\begin{array}{l}116 \cdot 4 \\
186 \cdot 5\end{array}$ & $\begin{array}{r}73 \cdot 3 \\
151.6\end{array}$ & $\begin{array}{l}132.5 \\
313.7\end{array}$ & $\begin{array}{r}7 \cdot 1 \\
31 \cdot 9\end{array}$ & $\begin{array}{l}13 \cdot 2 \\
25 \cdot 8\end{array}$ & $\begin{array}{l}23 \cdot 8 \\
53 \cdot 7\end{array}$ & $\begin{array}{r}1 \cdot 4 \\
10 \cdot 6\end{array}$ & $\begin{array}{r}2 \cdot 6 \\
12 \cdot 9\end{array}$ & $\begin{array}{r}2 \cdot 5 \\
36 \cdot 6\end{array}$ \\
\hline South Wales & $\begin{array}{l}E \\
F \\
H \\
I \\
V \\
W\end{array}$ & $\begin{array}{r}38 \\
143 \\
68 \\
42 \\
22 \\
105\end{array}$ & $\begin{array}{r}80 \\
102 \\
70 \\
58 \\
153 \\
91\end{array}$ & $\begin{array}{r}52 \\
87 \\
87 \\
68 \\
148 \\
46\end{array}$ & $\begin{array}{l}55.9 \\
54.7 \\
52.0 \\
52.1 \\
55.2 \\
53.2\end{array}$ & $\begin{array}{l}56.8 \\
54.9 \\
55 \cdot 4 \\
57 \cdot 3 \\
55 \cdot 2 \\
55 \cdot 5\end{array}$ & $\begin{array}{l}71.4 \\
71 \cdot 5 \\
70.7 \\
71 \cdot 2 \\
70.9 \\
69.3\end{array}$ & $\begin{array}{l}215 \cdot 3 \\
315 \cdot 2 \\
201 \cdot 3 \\
176 \cdot 3 \\
226 \cdot 8 \\
167 \cdot 4\end{array}$ & $\begin{array}{l}192.8 \\
296.8 \\
157.0 \\
165.3 \\
166.7 \\
162.6\end{array}$ & $\begin{array}{l}214 \cdot 2 \\
370 \cdot 8 \\
223 \cdot 1 \\
223 \cdot 4 \\
269 \cdot 6 \\
219.9\end{array}$ & $\begin{array}{l}26 \cdot 3 \\
58 \cdot 0 \\
47 \cdot 1 \\
38 \cdot 1 \\
36 \cdot 3 \\
47 \cdot 6\end{array}$ & $\begin{array}{l}48 \cdot 8 \\
60 \cdot 8 \\
48 \cdot 6 \\
50 \cdot 0 \\
26 \cdot 8 \\
45 \cdot 1\end{array}$ & $\begin{array}{l}50.0 \\
52.9 \\
52.9 \\
75.0 \\
45.9 \\
50.0\end{array}$ & $\begin{array}{l}10.5 \\
21.0 \\
11.8 \\
19.0 \\
22.7 \\
12.8\end{array}$ & $\begin{array}{r}15.0 \\
30.4 \\
15.7 \\
13.8 \\
7.2 \\
10.3\end{array}$ & $\begin{array}{l}17 \cdot 3 \\
26 \cdot 4 \\
19 \cdot 5 \\
25 \cdot 0 \\
19 \cdot 6 \\
28 \cdot 4\end{array}$ \\
\hline Lancashire & $\mathbf{A}$ & 17 & 122 & 29 & $46 \cdot 6$ & $50 \cdot 6$ & $70 \cdot 7$ & $202 \cdot 9$ & $207 \cdot 7$ & $390 \cdot 6$ & $17 \cdot 6$ & $31 \cdot 1$ & $55 \cdot 2$ & 0.0 & 6.6 & $13 \cdot 8$ \\
\hline isent & B & 74 & 62 & 70 & $54 \cdot 5$ & $54 \cdot 5$ & $70 \cdot 0$ & $181 \cdot 8$ & $145 \cdot 7$ & $228 \cdot 3$ & $20 \cdot 3$ & $30 \cdot 6$ & $41 \cdot 4$ & $2 \cdot 7$ & $3 \cdot 2$ & $14 \cdot 3$ \\
\hline North Wales & $\mathrm{L}$ & 23 & 127 & 117 & $54 \cdot 0$ & $54 \cdot 7$ & $72 \cdot 0$ & $235 \cdot 8$ & $182 \cdot 4$ & $271 \cdot 0$ & $26 \cdot 1$ & $25 \cdot 2$ & $32 \cdot 5$ & $4 \cdot 3$ & 5.5 & $8 \cdot 5$ \\
\hline Cumbria & $\mathbf{M}$ & 153 & 82 & 66 & $51 \cdot 4$ & $49 \cdot 5$ & $72 \cdot 6$ & $187 \cdot 2$ & 107.9 & $279 \cdot 5$ & $15 \cdot 7$ & $17 \cdot 1$ & $48 \cdot 5$ & $2 \cdot 0$ & 4.9 & 13.6 \\
\hline All men & & 2255 & 1953 & 1943 & $52 \cdot 7$ & $54 \cdot 3$ & $71 \cdot 1$ & $172 \cdot 8$ & $148 \cdot 7$ & $226 \cdot 2$ & $26 \cdot 9$ & $28 \cdot 2$ & $41 \cdot 0$ & $6 \cdot 6$ & $8 \cdot 7$ & $14 \cdot 7$ \\
\hline
\end{tabular}

in age, dust exposure, smoking habit, and differences between collieries in the effect of dust.

Figures 3 and 4 show the frequencies of category $0 / 1$ or greater and category $2 / 1$ or greater opacities respectively predicted by the statistical models over a range of dust exposure and for three selected ages after taking account of other factors. For both these categories of opacities the lines for miners and for ex-miners are virtually parallel, illustrating the similarity of the response to dust exposure in these groups of men. For the cateogry $2 / 1$ or greater opacities no statisticallly significant difference in frequency was shown between miners and ex-miners under $65(0 \cdot 15$ $<\mathrm{p}<0 \cdot 2$ ).

For category $0 / 1$ or greater opacities, the predicted frequencies were slightly higher in given ranges of dust exposure and age for ex-miners than miners $(0.025<$ $p<0.05$ ) and this appeared to be the result of a small difference in the response in these two groups of men to age.

The relation of both categories of opacities with age is obvious from the figures $(p<0.001$ for each category). In the case of category $0 / 1$ or greater opacities (fig 3 ) it can be seen that among young men (men aged 40 are illustrated) ex-miners tended to have slightly lower frequencies of opacities than miners, but among older men (men aged 60 are illustrated) ex-miners have higher frequencies than miners. The term in the logistic model representing the difference in age effect between miners and ex-miners approached statistical significance $(0.1>p>0.05)$. The difference in effect of age partly accounted for the difference in frequency of these opacities between miners and ex-miners under 65. Although the remainder of this difference has not been explained, it did not appear to result from a different response to dust exposure, for the term in the logistic model representing the difference in dust effect between miners and ex-miners could easily have arisen by chance $(0.6>p>0.5)$.

The fit of the observed to predicted frequencies was generally good, confirming the adequacy of the statistical model. The results were not substantially altered when total time contributing to exposure was allowed for.

Comparison of the self trained panel recordings of categories of small rounded opacities with those of the 


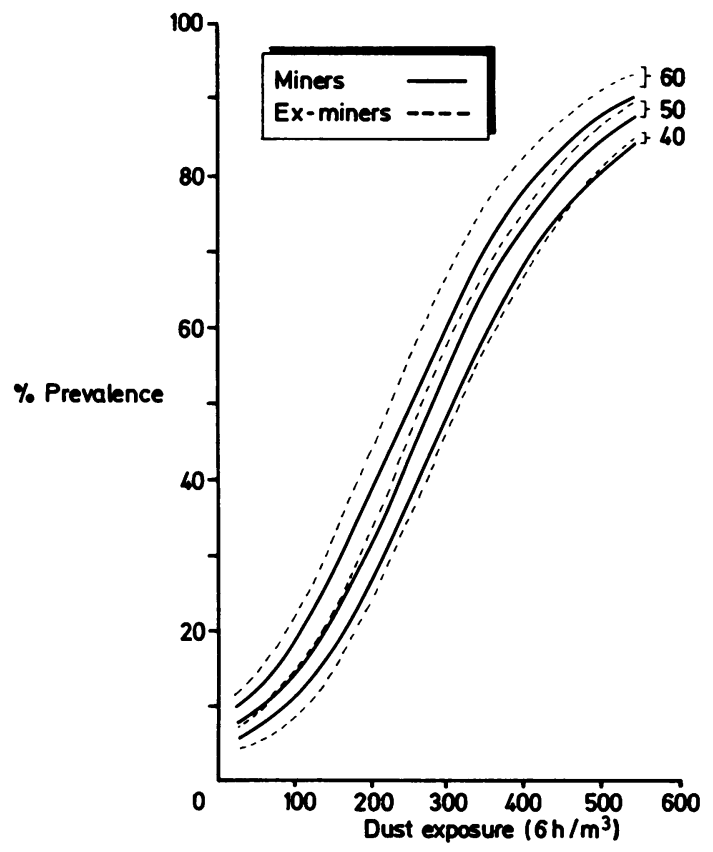

Fig 3 Predicted prevalence of small rounded opacities category $0 / 1$ or greater in relation to dust exposure and for three ages (men aged 40,50, and 60) in miners and ex-miners under 65. These curves are averages of fitted logistic curves for smokers only, over collieries, using equal weights for both miners and ex-miners.

experienced medically qualified panel in a subset of 760 radiographs showed that the self trained panel tended to classify higher on the ILO scale of profusion than the medical panel (table 5).

\section{Discussion}

Diligent efforts were made in this study to trace and examine all the members of the sample population, and it was possible to examine a substantial $61 \%$ of the survivors. We have no information about the respiratory health of those survivors who did not

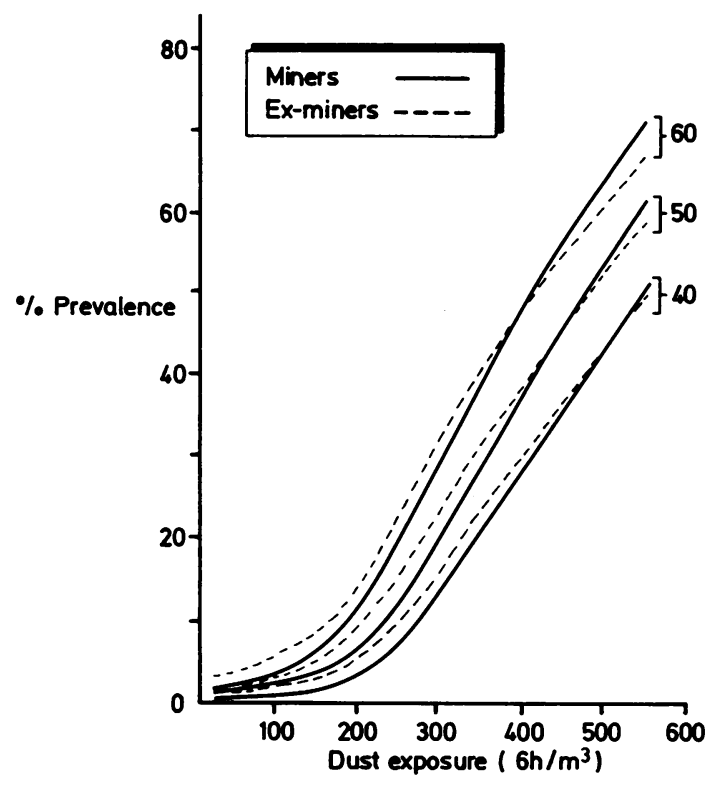

Fig 4 Predicted prevalence of small rounded opacities category 2/1 or greater in relation to dust exposure and for three ages (men aged 40,50, and 60) in miners and ex-miners under 65. See caption to fig 1 for further description of derivation of curves.

attend the follow up survey, but some information $\frac{2}{\varnothing}$ about their health at the time of first survey was available. Analysis of the relations between dust exposure and simple pneumoconiosis at that time suggested that men subsequently not examined had a slightly less severe response to their dust exposure than examined men. Thus whereas we are unable to make any direct assessment of the effect of non-response on our results, this finding does provide some reassurance that men not examined at follow up were unlikely to have had more severe reactions to dust than men examined.

In this study the chest radiographs were interpreted according to the ILO classification by a panel of self $\rightarrow$ trained readers, most of whom were not medically

Table 5 Comparison of median readings for profusion of small rounded opacities for five self trained readers and three medically trained readers

\begin{tabular}{|c|c|c|c|c|c|c|}
\hline & & & \multicolumn{3}{|c|}{ Self trained readers } & \multirow[b]{2}{*}{ All } \\
\hline & & & $\begin{array}{l}\text { Categor } \\
0 /-, 0 / 0\end{array}$ & $\begin{array}{l}\text { nall rounded } \\
0 / 1 \text { to } 1 / 2\end{array}$ & $\begin{array}{l}\text { acities } \\
2 / 1 \text { or greater }\end{array}$ & \\
\hline \multirow[t]{2}{*}{ Medically qualified readers } & $\begin{array}{l}\text { Category of small rounded } \\
\text { opacities }\end{array}$ & $\begin{array}{l}0 /-, \quad 0 / 0 \\
0 / 1 \text { to } 1 / 2 \\
2 / 1 \text { or greater }\end{array}$ & $\begin{array}{r}569 \\
4 \\
0\end{array}$ & $\begin{array}{r}100 \\
27 \\
1\end{array}$ & $\begin{array}{r}5 \\
45 \\
9\end{array}$ & $\begin{array}{r}674 \\
76 \\
10\end{array}$ \\
\hline & & All & 573 & 128 & 59 & 760 \\
\hline
\end{tabular}


qualified. This panel's readings of simple pneumoconiosis have been shown to be reproducible, and their classifications in other studies have confirmed relations of dust exposure with radiographic appearances which had been shown or suggested in earlier readings by experienced medically qualified readers. ${ }^{711}$ A comparison in a small number of radiographs in the present study between their readings and those of three medically qualified readers experienced in the interpretation of the appearances of pneumoconiosis showed that the self trained panel recorded higher prevalences of simple pneumoconiosis than the medical panel, and this should be borne in mind when examining the prevalences of pneumoconiosis recorded here. This difference is unlikely to have affected the conclusion on differences in effects of dust exposure from the study, since selftrained panel readings were used throughout. Furthermore two different levels of profusion of opacities were examined, and the same conclusions were reached in both.

In other work prevalence of simple pneumoconiosis has been found to be related to total time worked as well as to dust exposure. ${ }^{2}$ In our study total time worked was not found to contribute to the prediction of simple pneumoconiosis after allowing for dust exposure, and this is probably because we also allowed for the effects of age, to take account of differences in the age structure of our populations. Since category $2 / 1$ or greater small rounded opacities are highly likely in almost all individuals in this population to represent pneumoconiosis and not other, non-occupational disease, the relation with age may represent a residual effect of exposure to dust that the exposure estimates did not take into account, for it is possible that exposures in the period before research measurements started were higher than has been estimated. Alternatively, the period during which the dust was resident in the lung may have influenced the development of pneumoconiosis, as has recently been shown in the case of progressive massive fibrosis. ${ }^{12}$

The results of this study show clearly that the dust/pneumoconiosis relations for category $2 / 1$ or greater small rounded opacities are not distinguishably different for miners and ex-miners, and that for category $0 / 1$ or greater opacities, the response to dust exposure also appeared to be the same, though a slightly greater response to age was indicated in the ex-miners. This difference in the lower categories of profusion could be the result of disease other than pneumoconiosis, since in other, non-mining populations, age related small rounded opacities of low profusion may be shown. ${ }^{13}$ Whereas this analysis was not primarily concerned with the effects of smoking on radiographic appearances, ex-smokers were found to have a greater response to dust exposure in terms of the presence of category $0 / 1$ or greater opacities than other men, and it was necessary to allow for this in studying the effects of dust exposure. No smoking effect was shown for $2 / 1$ or greater opacities, however, and this result is consistent with a previous study ${ }^{14}$ of the influence of smoking. If confirmed by other studies this result could possibly indicate that men who gave up smoking because they recognised that their respiratory health was being affected included some who were suffering a greater than average effect of exposure to dust.

We conclude that previous estimates of dust/simple pneumoconiosis relationships based on studies of working British miners also adequately describe those in miners aged under 65 who have left the industry.

This study has spanned several years and many of our colleagues have made substantial contributions to it. In particular we wish to thank Dr M Jacobsen, who initiated and advised on the project, and the miners and ex-miners who took part.

The work was supported by the Commission of the European Communities (Contract 72465-16/8/002) and by the National Coal Board of Great Britain.

\section{Appendix}

\section{STATISTICAL METHODS}

The structure of the logistic equation used to describe relations between pneumoconiosis frequency at follow up survey and covariates of interest is briefly as follows.

Within cells determined by 24 collieries, three groups of miners and ex-miners (working miners, exminers under 65 , and ex-miners 65 or more at follow up survey) and four groups defined by smoking status (current cigarette smokers, current pipe or cigar smokers, ex-smokers, and never smokers), the probability of a man's having category $0 / 1$ simple pneumoconiosis or greater (or category $2 / 1$ or greater) was assumed to be a linear logistic function of total dust exposure (g hours $/ \mathrm{m}^{3}$ ) and age (years). Intercepts and dust coefficients were constrained to have an additive structure over cells, while three age terms only were fitted, one for each group of men.

The following table is an extract from the complete set of fitted regression coefficients.

The statistical significance of the difference in pneunociosis frequency between miners and ex-miners under 65 was examined by considering the decrease of log-likelihood when variables 2,4 , and 6 were dropped from the fitted equations.

The goodness of fit of the logistic equations was assessed by grouping cases into 30 sets of 200 (and one set of 151) by increasing dust exposure, and com- 
Soutar, Maclaren, Annis, and Melville $\overline{\bar{\alpha}}$

\begin{tabular}{|c|c|c|c|c|c|c|c|}
\hline \multirow[t]{2}{*}{ No } & \multirow{2}{*}{$\frac{\text { Variable }}{\text { Description }}$} & \multicolumn{6}{|c|}{ Coefficient (standard error) $t$} \\
\hline & & \multicolumn{3}{|c|}{ Analysis of $0 /+$} & \multicolumn{3}{|c|}{ Analysis of $2 / 1+$} \\
\hline $\begin{array}{l}1 \\
2 \\
3 \\
4\end{array}$ & $\begin{array}{l}\text { Intercept (miners)* } \\
\text { Intercept (ex-miners under 65) minus intercept (miners) } \\
\text { Dust exposure (miners)* } \\
\text { Dust exposure (ex-miners under } 65 \text { ) minus dust }\end{array}$ & $\begin{array}{r}-3.4769 \\
-1 \cdot 1268 \\
0.0045\end{array}$ & $\begin{array}{l}(0.5662) \\
(0.6916) \\
(0.0012)\end{array}$ & $\begin{array}{r}-6 \cdot 14 \\
-1.63 \\
3.64\end{array}$ & $\begin{array}{r}-8.3924 \\
1.3314 \\
0.0059\end{array}$ & $\begin{array}{l}(1 \cdot 1773) \\
(1 \cdot 3704) \\
(0 \cdot 0018)\end{array}$ & $\begin{array}{r}-7 \cdot 13 \\
0.97 \\
3.27\end{array}$ \\
\hline $\begin{array}{l}5 \\
6\end{array}$ & $\begin{array}{l}\text { exposure (miners) } \\
\text { Age (miners)* } \\
\text { Age (ex-miners under } 65 \text { ) minus age (miners) }\end{array}$ & $\begin{array}{l}0.0005 \\
0.0313 \\
0.0220\end{array}$ & $\begin{array}{l}(0.0009) \\
(0.0087) \\
(0.0129)\end{array}$ & $\begin{array}{l}0.54 \\
3 \cdot 59 \\
1 \cdot 71\end{array}$ & $\begin{array}{r}-0.0017 \\
0.0733 \\
-0.0115\end{array}$ & $\begin{array}{l}(0.0011) \\
(0.0180) \\
(0.0244)\end{array}$ & $\begin{array}{r}-1.43 \\
4.08 \\
-0.47\end{array}$ \\
\hline
\end{tabular}

*These terms are for smokers at colliery $\mathbf{A}$.

puting total observed frequency of pneumoconiosis and total predicted by the fitted function, separately for each set. Comparison of observed and expected frequencies was carried out by means of a chi-square test. This procedure was repeated using age instead of dust exposure. All tests failed to show significant lack of fit $(p>0 \cdot 5)$. A one sample run test on the algebraic signs of the quantities, observed minus expected, was also not significant.

\section{References}

${ }^{1}$ Jacobsen M, Rae S, Walton WH, Rogan JM. The relationship between pneumoconiosis and dust exposure in British coal mines. In: Walton WH, ed. Inhaled particles III. Old Woking, Surrey: Unwin Bros, 1971:903-19.

${ }^{2}$ Hurley JF, Burns J, Copland L, Dodgson J, Jacobsen M. Coalworkers' simple pneumoconiosis and exposure to dust at 10 British coalmines. Br J Ind Med 1982;39:120-7.

${ }^{3}$ Rogan JM, Rae S, Walton WH. The National Coal Board's pneumoconiosis field research-an interim review. In: Inhaled particles and vapours II. Oxford and New York: Pergamon Press, 1966:493-508.

${ }^{4}$ International Labour Office. Proccedings of the 3rd International Conference on Pneumoconiosis, Sydney, 1950. Geneva: ILO, 1953.

${ }^{5}$ Miller BG, Jacobsen M. Dust exposure, pneumoconiosis, and mortality of coalminers. Br J Ind Med 1985;42:723-33.

${ }^{6}$ Rae S, Walker DD, Attfield MD. Chronic bronchitis and dust exposure in British coalmines. In: Walton WH, ed. Inhaled particles III. Old Woking, Surrey: Unwin Bros, 1971:883-94.

${ }^{7}$ Copland L, Burns J, Jacobsen M. Classification of chest radio- $\mathbb{D}$ graphs for epidemiological purposes by people not experienced in the radiology of pneumoconiosis. $B r J$ Ind Med $\vec{\omega}$ 1981;38:254-61.

${ }^{8}$ International Labour Office. ILO U/C international classification of $\vec{\sim}$ radiographs of the pneumoconiosis 1971. Geneva: ILO, 1972. (Occupational Safety and Health Series No 22.)

${ }^{9}$ Melville AWT, Paris I, Hurley JF, Soutar CA. Pneumoconiosis, hung function and exposure to airborne dust: epidemiological research to compare responses of working coalminers with responses of ex-miners. Edinburgh: Institute of Occupational Medicine, 1979. (IOM report No TM/79/11.)

${ }^{10}$ Dodgson J, Hadden GG, Jones CO, Walton WH. Characteristics of the airborne dust in British coalmines. In: Walton WH. $\vec{\theta}$ Inhaled particles III. Vol 2. Old Woking, Surrey: Unwin Bros, 1971.

${ }^{11}$ Soutar CA, Gauld S, Lloyd M, Copland LH, Hurley JF. Epidemiological and clinical studies of polyvinylchloride workers. Edinburgh: Institute of Occupational Medicine, 1981. (IOM report $\mathrm{TM} / 81 / 8$.)

${ }^{12}$ Hurley JF, Maclaren WM, Alexander WP, et al. Factors influencing the occurrence of progressive massive fibrosis in British coalminers. Edinburgh: Institute of Occupational Medicine, 1984. (IOM report No TM/84/2.)

${ }^{13}$ Soutar CA, Copland LH, Thornley PE, et al. Epidemiological study of respiratory disease in workers exposed to polyvinylchloride dust. Thorax 1980;35:644-52.

${ }^{14}$ Jacobsen M, Burns J, Attfield MD. Smoking and coalworkers' simple pneumoconiosis. In: Walton WH, ed. Inhaled particles IV Vol 2. Oxford: Pergamon Press, 1977:759-72. 